\title{
Bonn-København erklæringerne af 1955
}

i mere præcist lys

Af Anders Ture Lindstrøm

De såkaldte Bonn-København erklæringer, der satte gang i udviklingen af mere positive relationer mellem dansk og tysk i grænselandet, har haft 30-års jubilæum i 1985. I denne artikel skildres baggrunden for erklæringerne og forhandlingerne om dem, idet forfatteren bl.a. har kunnet bygge på kildemateriale, der ikke før har været tilgængeligt.

\section{Introduktion}

Det tyske sammenbrud i 1945 efterfulgtes syd for grænsen af en eksplosivt voksende danskorienteret bevægelse. Fra tysk side bekæmpedes denne bevægelse, der udgjorde en separatistisk fare, energisk og hårdhændet. Da det 1948-49 var klart, at de danskorienterede sydslesvigere så småt begyndte at svækkes politisk, svingede den daværende SPDdelstatsregering i Kiel i forståelse med de danske socialdemokrater om og indledte en mildere mindretalspolitik. Denne udmøntedes først og fremmest i den såkaldte Kielerklæring af 26. september 1949, hvor det danske mindretal fik sine rettigheder garanteret. Erklæringen var imidlertid ikke så meget værd, da grænsetyske kredse gik stærkt imod, og fremtrædende CDU-politikere direkte distancerede sig fra den. ${ }^{1}$

Det betød voldsomme problemer for det danske mindretal i 1950, da en borgerlig koalitionsregering kom til magten. Først i marts 1955 blev den danske og den vesttyske regering enige om de såkaldte BonnKøbenhavnerklæringer, der nyformulerede både det tyske og det danske mindretals rettigheder og skabte mere holdbare rammer for de fremtidige mindretalsforhold.

Den følgende korte og summariske skildring af forløbet op til disse erklæringer bygger først og fremmest på den såkaldte gråbog om de 
dansk-tyske forhandlinger. Den består af en indledende fremstilling ved professor, dr.phil. Troels Fink, Udenrigsministeriets daværende konsulent i sydslesvigske anliggender, samt de vigtigste dokumenter og referater. Gråbogen har været og er stadig beregnet til fortrolig tjenstlig brug for politikere og embedsmænd, men er her benyttet med særlig tilladelse fra Udenrigsministeriet.

\section{Fra grænsekamp til dansk-tyske forhandlinger}

Ved landdagsvalget i Slesvig-Holsten den 9. juli 1950 mistede SPD regeringsmagten. Socialdemokraterne måtte afgive den til CDU og de andre ikke-socialistiske partier. Det bør i denne forbindelse bemærkes, at Slesvig-Holstens sociale og økonomiske krise ved dette valg på markant vis blev demonstreret. BHE, Block der Heimatvertriebenen und Entrechteten, fik som ny politisk magtfaktor og politisk interesseparti for store dele af flygtningemasserne ikke mindre end $23,4 \%$ af stemmerne. Med de svære økonomiske problemer var den politiske stabiliseringsproces kun lige begyndt. Overgangen til borgerligt styre betød, at den begyndende dansk-tyske forståelse begyndte at smuldre. Indflydelsesrige kredse i CDU havde aldrig accepteret Kiel-erklæringen. De følgende år 1950-1955 var efter dansk opfattelse en periode med en meget smålig og traditionel tysk-nationalistisk politik, en tid med meget bevidst gennemførte chikanerier mod det danske mindretal. Blandt de mere kendte er aktionen mod den daværende lærer, senere landdagsmand og chefredaktør Karl Otto Meyer, der i flere år fik frataget sin undervisningstilladelse, fordi han agiterede mod vesttysk oprustning.

Væsentlige træk i de borgerlige partiers politik blev en sammenkædning af det danske og det tyske mindretals forhold, kravet om en dansktysk traktat om mindretalsproblemerne samt en målbevidst svækkelse af mindretallets medlemsskare og politiske indflydelse.

Den danskorienterede bevægelse i Sydslesvig skulle reduceres og afpolitiseres, indtil den var skrumpet ind til det »ægte« mindretal. Endelig ønskede grænsetyske kredse at hjælpe det tyske mindretal i Nordslesvig, der som følge af besættelsestiden var blevet alvorligt berørt af det danske retsopgør. Det danske mindretal i Sydslesvig befandt sig således i strid modvind.

De internationale konjunkturer ændrede ligeledes danske og sydslesvigske arbejdsvilkår. Forbundsrepublikken Tyskland var blevet 
oprettet i 1949, og fra nu af bevægede den vesttyske stat sig støt frem mod en stadig mere selvstændig status. Det svækkede den danske regerings muligheder for at intervenere direkte til fordel for mindretallet. Kombinationen af borgerlige koalitionsregeringer i både Bonn og Kiel kom til at betyde vesttysk interesse for en mellemstatslig aftale, en regulær traktat om mindretal og grænseproblemer, skønt en sådan konstruktion lige siden 1864 altid pure var blevet afvist fra dansk side.

Mest kendt for sit arbejde med målbevidst at svække den dansk-sydslesvigske bevægelse er afdøde Friedrich Wilhelm Lübke, der var ministerpræsident i Slesvig-Holsten fra juni 1951 til oktober 1954. Han har måske ikke været den mest elskede, men ubestridt en af de dygtigste politikere i efterkrigstidens Slesvig-Holsten. F.W. Lübke gjorde en ihærdig indsats for at få den forarmede delstat på fode. I den forbindelse udnyttede han behændigt Bonn-regeringens behov for politisk opbakning fra de ikke-socialistiske delstatsregeringer i forbundsrådet. Lübke gjorde i Bonn tillige kraftigt opmærksom på grænselandsproblemerne mod nord og agiterede således i marts 1952 fra øget støtte til det tyske arbejde i Sydslesvig på grund af den såkaldte danske »kulturoffensiv . $^{2}$

Den nationalpolitisk spændte situation gjorde det desuden psykologisk vanskeligere at stimulere erhvervsklimaet, og flygtningene pressede på for at få reduceret den stadig usædvanlig høje arbejdsløshed. Op til midt i halvtredserne boede der stadig mange tusind mennesker $i$ de slesvig-holstenske flygtningelejre. Den tyske historiker Gabriele Stüber har beskrevet de værste år, hvor »krisekriminalitet« var overlevelsesstrategi for mange, i sin bog Der Kampf gegen den Hunger 1945$1950 .^{3}$

Af stor praktisk og politisk-psykologisk betydning blev det store egnsudviklingsprojekt Program Nord, der fra 1953 gradvis har betydet modernisering og jordreformer for meget betydelige arealer først i det fattigste Sydslesvig, siden også i Holsten.

De dansksindede sydslesvigere blev generet af Lübkes nålestikspolitik, men især også af bestræbelserne for at gøre det vanskeligt eller næsten umuligt for dem at opnå politisk repræsentation $\mathrm{i}$ landdagen $\mathrm{i}$ Kiel. Spærreklausulen i den slesvig-holstenske valglov, der skulle holde de mindste partier ude, blev 1951-52 hævet fra 5\% til 7,5\%. Det ville udelukke dem fra repræsentation i den næste landdag, sådan som det vigende danske stemmetal blev fordelt. En retskendelse fra forbundsforfatningsdomstolen i Karlsruhe i foråret 1952 medførte, at 
spærreklausulen atter blev nedsat til 5\%, men dette ville sandsynligvis ikke være nok til at sikre fornyet landdagsrepræsentation. Den slesvigholstenske landsregerings officielle politik var fortsat klar.

De dansksindede sydslesvigere skulle afgive en loyalitetserklæring. Det ville bl.a. betyde, at de gav afkald på enhver drøm om grænserevision, hvis de ville have mildnet den slesvig-holstenske valglovs bestemmelser. Spærreklausulen var et af de få gode kort på hånden, den slesvig-holstenske landsregering rådede over, skrev den tidligere CDU-ministerpræsident i Kiel Kai-Uwe von Hassel mange år senere." De danske sydslesvigeres repræsentanter så ingen grund til at aflægge loyalitetserklæringer på linje med den hjemmetyske erklæring efter krigens afslutning i 1945. De havde været loyale og bragt store ofre for diktaturet 1933-1945. Fra tysk side anså man imidlertid en loyalitetserklæring for at være nødvendig. Så længe der ikke var afgivet en loyalitetserklæring eller sluttet en dansk-tysk traktat, kunne det danske mindretal leve af at holde grænsespørgsmålet åbent, og før der var afgivet en erklæring, ville de førende tyske grænsepolitikere ikke stille garantier for en egentlig mindretalsbeskyttelse. ${ }^{5}$ I øvrigt vedblev tyske politikere $\mathrm{i}$ Kiel at hævde, at den omstridte 7,5\% klausul især var rettet mod yderliggående grupperinger på højre og venstre fløj, hvad man med en vis ret måtte indrømme for begyndelsen af halvtredsernes vedkommende, hvor der bl.a. opstod forskellige nynazistiske organisationer. ${ }^{6}$

Debatten om repræsentationsspørgsmålet trak ud. Tyske grænsepolitikere havde ikke så travlt. Forbundsdagsvalget havde givet stor dansk tilbagegang. 44.000 stemmer eller 3,3\% af stemmerne gav ikke valg. Med en 5\% klausul ville de danske landdagsmænd i Kiel miste deres mandater ved valget i $1954 .^{7}$

Officielt, måske også af taktiske grunde, udtrykte ministerpræsident F.W. Lübke sig ikke alt for kategorisk om mindretalsproblemerne. Han ville have en loyalitetserklæring, men gav indtryk af, at han ville strække sig "... så vidt, som overhovedet muligt, for at gøre den acceptabel for mindretallet. Lübke betonede, at han gerne ville skabe et godt forhold til Danmark og skabe ro i grænselandet; men han lagde ikke skjul på, at han mødte modstand fra forskellige sider inden for sine egne politiske kredse $\kappa^{8}$ Hele vinteren 1953-54 drøftedes valglovsproblemerne og de andre presserende mindretalsspørgsmål ivrigt syd for grænsen. Den borgerlige fløj i Slesvig-Holsten insisterede uforandret på, at en loyalitetserklæring var nødvendig af hensyn til roen i grænselandet. Grænsetyske kredse afviste fortsat de danske sydslesvigeres ønsker i sådanne vendinger, at man måtte antage, at de først og frem- 
mest satsede på et nyt alvorligt politisk nederlag for mindretallet ved landdagsvalget $i$ efteråret 1954. Et markant træk i den daværende slesvig-holstenske regerings politik var den officielle uvilje mod det, der opfattedes som venstreorienteret aktivitet $\mathrm{i}$ den danske bevægelse. SSV oplevede i øvrigt en ny svækkelse, da den særlige danske socialdemokratiske partiorganisation, SPF, der havde løsrevet sig fra SPD i 1946, i juni 1954 blev opløst. ${ }^{9}$

Den 11. august 1954 afviste forbundsforfatningsdomstolen en ny klage fra SSV og sikrede 5\%-klausulens fortsatte eksistens. Kun en valgsejr med et direkte mandat til SSV kunne nu give politisk repræsentation i landdagen. Men en tysk omlægning af valgkredsene i Flensborg-Harreslevområdet, den form for manipulation, der kaldes valggeometri, blokerede også denne sidste mulighed. Troels Fink skriver om dette: "... Denne ændring tydede på, at der fra tysk side blev lagt megen vægt på at tilføje det danske mindretal et nederlag ved det forestående valg; efter valget kunne der så forhandles om et eller andet surrogat for den direkte politiske repræsentation ${ }^{10}{ }^{10}$ Adskillige frygtede ny alvorlig tilbagegang for mindretallet; men landdagsvalget gik overraskende godt. SSV fik ved landdagsvalget september 1954 omkring 42.000 stemmer; men det var ikke nok til at opnå et direkte mandat. Valgresultatet førte til ny debat om den slesvig-holstenske spærreklausul. Fremtrædende danske politikere havde i løbet af 1954 forsigtigt markeret sympati for sydslesvigernes problemer, men ikke lagt op til nogen statspolitisk aktion. Men ved folketingets åbning udtrykte statsminister Hans Hedtoft ønske om, at mindretallet fik en rimelig mulighed for politisk repræsentation. For danske politikere var det noget af en selvfølge, at demokratiske stater førte en frisindet mindretalspolitik.

Før landdagsvalget havde der fra slesvig-holstensk side været luftet muligheder for »en storsindet« løsning. Det mærkede man ikke noget til efter valget, hvilket sandsynligvis skyldtes Lübkes alvorlige sygdom samt intern politisk uenighed i regeringskoalitionen. Lübkes egenrådige og noget patriarkalske stil kunne undertiden skabe en vis spænding. Den 11. oktober 1954 måtte Lübke træde tilbage. Han døde få dage efter. ${ }^{11}$ Hans efterfølger blev Kai-Uwe von Hassel, en politiker med grænselandserfaring, der havde arbejdet nært sammen med den afdøde ministerpræsident. Kai-Uwe von Hassel var tysk-national konservativ og borgerlig samlingspolitiker uden alt for sarte fornemmelser, når det gjaldt om at vise en vis overbærenhed overe for personer og grupper med belastet fortid fra perioden 1933-45. Han satsede på at 


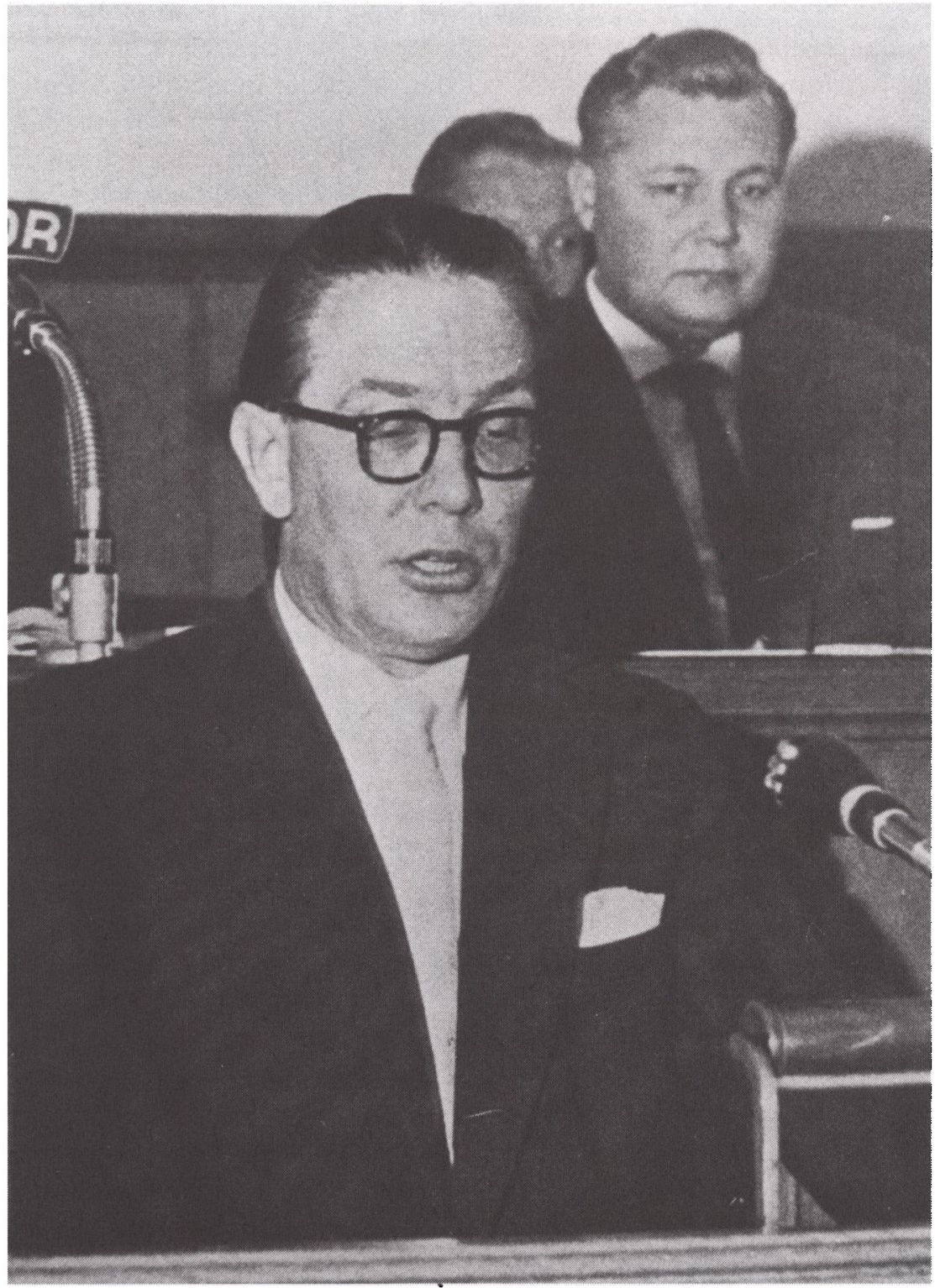

Kai-Uwe von Hassel. Han efterfulgte $1954 \mathrm{~F}$.W. Lübke som slesvig-holstensk ministerprasident. I granselandspolitikken gik han ind for en härd linje over for det danske mindretal og onskede ved at sammenkade de danske og tyske mindretalsproblemer at aftvinge danske indrommelser $i$ Nordslesvig. Som ministerprasident startede han $i 1954$ med at krave en dansk-tysk mindretalstraktat, men fulgte siden de politiske signaler fra Bonn og slog ind pd en blødere kurs over for det danske mindretal i Sydslesvig. 
fortsætte den politiske og økonomiske stabiliseringspolitik i den urolige delstat. Slesvig-Holsten havde radikale ideologiske traditioner, og mulighederne for ny uro på grund af nye yderliggående grupper og bevægelser kunne endnu ikke afvises. ${ }^{12}$

SPD i Kiel og Bonn havde i forståelse med de danske socialdemokrater siden 1948-1949 arbejdet for mere afspænding i Sydslesvig, således også for valglovsændringer. Det skete bl.a. ved en forespørgselsdebat i forbundsdagen den 19 . oktober 1954 , netop den dato, da folketinget drøftede spørgsmålet om Vesttysklands optagelse i NATO. Det er efterhånden velkendt, at netop dette spørgsmål førte til situationer af afgørende betydning for den videre udvikling af de danske repræsentationsproblemer i landdagen i Kiel, ligesom der omsider blev taget initiativer til en generel afklaring af de forskellige problemer i de dansktyske grænseregioner.

NATO-problematikken illustrerede`Danmarks fundamentalt ændrede udenrigs- og sikkerhedspolitiske situation. En ny stormagt, Sovjetunionen, satte nok sit stærke præg på hele Østersøregionen; men fra 1945 stod småstaten Danmark ikke alene i forholdet til Tyskland. Den svage neutralitetspolitik var fra 1949 blevet erstattet af et fast politisk og militært allianceforhold i NATO.

Danmark havde næppe noget valg i 1954, da det var lykkedes vestmagterne og Forbundsrepublikken at finde frem til en formel for vesttysk NATO-medlemskab. Forbundsrepublikkens meget betydelige militære og økonomiske potentiel talte mere internationalt end Danmarks beskedne ressourcer. Der var da også al mulig udsigt til, at det danske folketing ville ratificere den vesttyske indtræden i NATO. Men den socialdemokratiske mindretalsregering ville ikke blot have en klar afgørelse, den ønskede også en klar og stor parlamentarisk opbakning af det vesttyske medlemskab.

Det førte under Folketingets udenrigssdebat den 19. oktober 1954 til betydningsfulde politiske drøftelser af relevans for Sydslesvig-problemet kun 3 dage før det NATO-møde i Paris, hvor vesttyskerne officielt skulle indbydes.

Udenrigsminister H.C. Hansen havde tidligere vist interesse for en frisindet tysk mindretalspolitik; men han havde ikke officielt sammenkædet det vesttyske NATO-medlemskab og de sydslesvigske problemer. Dette overvejede derimod forskellige borgerlige kredse. Således havde fhv. udenrigsminister, den konservative Ole Bjørn Kraft i en tale den 12. oktober 1954 bl.a. sagt, at NATO-mødet den 22. oktober var den foreløbig sidste lejlighed til at varetage den særlige sydslesvigske inte- 
resser. ${ }^{13}$ Både Venstres politiske ordfører i denne runde, fhv. finansminister Thorkild Kristensen og Ole Bjørn Kraft fremhævede dette synspunkt i debatten den 19. oktober 1954.

Det hedder i gråbogen, at der i løbet af folketingsmødet var uformelle drøftelser om sagen. Et par glimt fra Venstres interne drøftelser på Christiansborg illustrerer udviklingen. Venstre havde et stærkt engagement i Sydslesvig-sagen, og op til udenrigsdebatten havde Venstres hovedbestyrelse i Sønderjylland samt Sydslesvigsk Udvalg (en stadig indflydelsesrig organisation, der fra 1945 havde samlet de kredse, der ønskede grænserevision) rettet henvendelse til parti og folketingsgruppe. I skrivelsen fra Venstres hovedbestyrelse hedder det bl.a.: "... Det bør pålægges Danmarks udenrigsminister til det yderste at fastholde, at det er en forudsætning for Danmarks tilslutning til Vesttysklands optagelse i NATO, at der skabes sikkerhed for, at de demokratiske rettigheder, som kampen står om, tilsikres den dansksindede befolkning i Sydslesvig. Venstres folketingsgruppe lagde indledende ud med, at Thorkild Kristensen skulle støtte mindretalsrettigheder og de dansksindede sydslesvigeres berettigede krav. Forskellige venstrepolitikere, således Jørgen Gram og Arnth Jensen, insisterede i løbet af dagens drøftelser fortsat på støtte til sydslesvigerne, og Thorkild Kristensen bemyndigedes af gruppen til at forhandle med udenrigsministeren om en acceptabel formulering. På gruppens møde kl. 18.45 blev det oplyst, at udenrigsministeren i Paris ville fremsætte synspunkter til opbakning af sydslesvigernes sag, og lidt senere på aftenen, at H.C. Hansen havde tiltrådt en tilføjelse til dagsordenen: ".... og samtidig opfordres udenrigsministeren til ved NATO-mødet $i$ Paris at fremføre de danske synspunkter angående de dansksindede sydslesvigeres interesser «. ${ }^{14}$

Resultatet af de forskellige indenrigspolitiske pres blev en dansk aktion, der bragte det for alle andre vestlige lande ikke særlig væsentlige spørgsmål om sydslesvigernes rettigheder ind på den internationale arena. H.C. Hansen var en klartseende taktiker, der havde sit politiske bagland i orden. Han var såre realistisk og derfor meget forsigtig med hensyn til Sydslesvig-problemerne.

I folketingsdebatten den 19. oktober 1954 om aftenen, hvor der fra Venstre og de konservative blev presset på for at opnå et dansk initiativ, sagde udenrigsminister H.C. Hansen bl.a.: »Jeg har til hensigt på det forestående NATO-møde i Paris at fremsætte en udtalelse om dette spørgsmål i overensstemmelse med mine bemærkninger i min tale $i$ formiddags. Og jeg vil gerne føje til, at jeg skal bestræbe mig for i så vid 


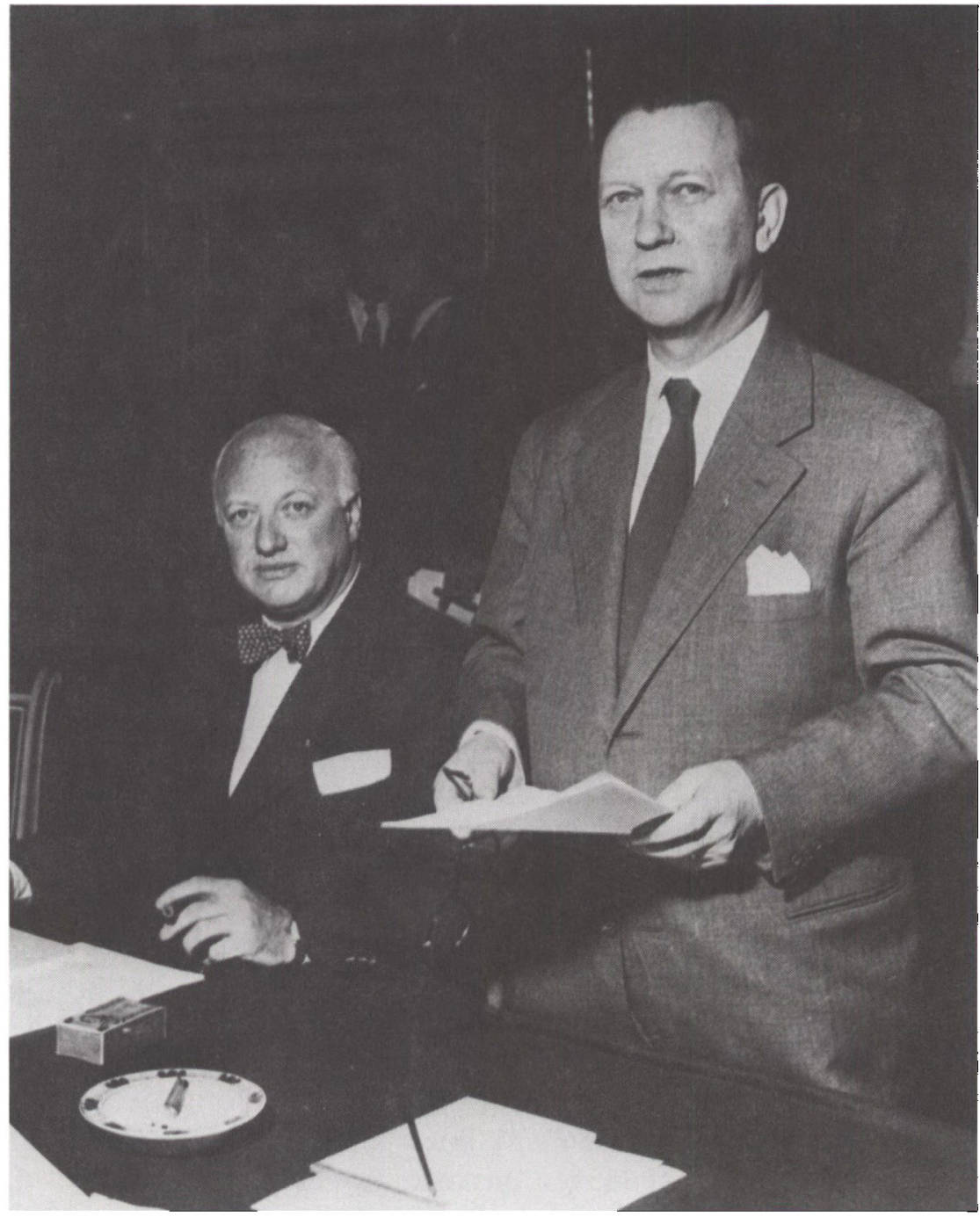

H. C. Hansen, den socialdemokratiske politiker, der var udenrigsminister 1953-58 og desuden statsminister 1955-60. Som udenrigsminister var $H$. C. Hansen interesseret $i$ en mere frisindet tysk mindretalspolitik, men havde oprindelig ikke forsogt officielt at sammenkade det vesttyske NATO-medlemskab og de sydslesvigske mindretalsproblemer. $H$. C. Hansen var såre realistisk og derfor forsigtig, da han efter borgerligt pres officielt fremforte de danske sydslesvigeres problemer pd NATO-modet i Paris den 22. oktober 1954. H. C. Hansen prasenterede problemerne med elegance og hans ord blev velvilligt modtaget fra tysk side. Under de efterfolgende forhandlinger $i 1955$ lagde han en betydelig professionalisme for dagen. - På billedet ses til venstre for H. C. Hansen Udenrigsministeriets direktør Nils Svenningsen. (Det kgl. Bibliotek) 
udstrækning, som det må findes fornuftigt og forsvarligt ved tilrettelæggelsen af udtalelsen, at tage hensyn til de forskellige udtalelser om hele spørgsmålet, som er fremsat her under debatten«.

Med udenrigsministerens ord var Sydslesvig-problematikken for alvor kommet $\mathrm{i}$ forgrunden. "Dermed var det afgørende skridt taget", hedder det i gråbogens fremstilling. Danmarks udenrigsminister og regeringen havde vist vilje til at gå ikke så lidt ud over normal praksis i et spørgsmål, som de fleste NATO-allierede slet ikke interesserede sig for. Da H.C. Hansen i løbet af den afsluttende udenrigsdebat blev presset yderligere, præciserede han, at der var klare grænser for den danske regerings og udenrigspolitiks formåen. Han ville gøre, hvad han kunne, men ville ikke lade sig binde på hænder og fødder. Og et dansk initiativ på internationalt plan i forbindelse med NATO-mødet var langtfra risikofrit. $^{15}$

\section{Dansk-tyske spændinger tages op ved NATO-mødet i Paris 1954}

Udviklingen i det dansk-tyske grænseproblem havde naturligt afspejlet de internationale konjunkturer. Efterhånden som Forbundsrepublikken økonomisk kom til kræfter og blev indpasset i det vestlige samarbejde, var de danske muligheder svundet for at støtte sydslesvigske krav. Foreløbig var det officielle krav i Kiel som nævnt stadig en loyalitetserklæring fra mindretallet med påfølgende begravelse af enhver forventning om grænserevision. I Bonn var man interesseret $i$ en regulær mindretalstraktat. Men der var nuancer i de officielle tyske synspunkter. Det vesttyske udenrigsministerium var ikke tilhænger af den hårde slesvig-holstenske linje. Fortsat grænsekamp mod et vigende mindretal havde ikke noget formål og belastede blot forholdet mellem Forbundsrepublikken og Danmark. Men det vesttyske udenrigsministerium og forbundsregeringen ønskede ikke at lægge åbent pres på landsregeringen i Kiel. Et sådant pres fra Bonn kunne svække Kiels forhandlingsposition.

$\mathrm{Nu}$ markerede udenrigsminister H.C. Hansen så det officielle danske ønske om en mere frisindet tysk mindretalspolitik i Sydslesvig. Det gjorde han på NATO-mødet i Paris den 22. oktober 1954, hvor forbundskansler Dr. Konrad Adenauer og statssekretær Dr. Hallstein deltog som observatører. Disse var efter alt at dømme i tide blevet orienteret om de specielle danske synspunkter. Allerede inden NATO-mødet havde der være kontakt mellem Bonn og Kiel om Sydslesvig. ${ }^{16}$ Det 
fremgår af gråbogens formuleringer, at udenrigsminister H.C. Hansen ikke anså sin opgave på NATO-mødet for at være særlig let.

Regeringen havde jo også tidligere afvist en egentlig statspolitisk aktion; men nu, hvor den kom, måtte man omhyggeligt søge efter en anvendelig formel. Henvendelsen blev formet som en appel til Bonn om en frisindet politik: "Der var ikke tale om at fremsætte en opfordring til at føre direkte dansk-tyske forhandlinger, man måtte håbe, at tyskerne af egen drift ville slå ind på en politisk retning, der ville føre til en bedre atmosfære i det dansk-tyske forhold ${ }^{17} .{ }^{17}$ Man havde fra dansk side i øvrigt støttet tanken om at indbyde Dr. Adenauer til mødet, og Udenrigsministeriet tillagde hans personlige deltagelse væsentlig betydning for, at udfaldet blev så godt. "Som forholdene udviklede sig, må man anse det for at være et stort held, at Dr. Adenauer var tilstede, da sagen blev fremført . $^{18}$

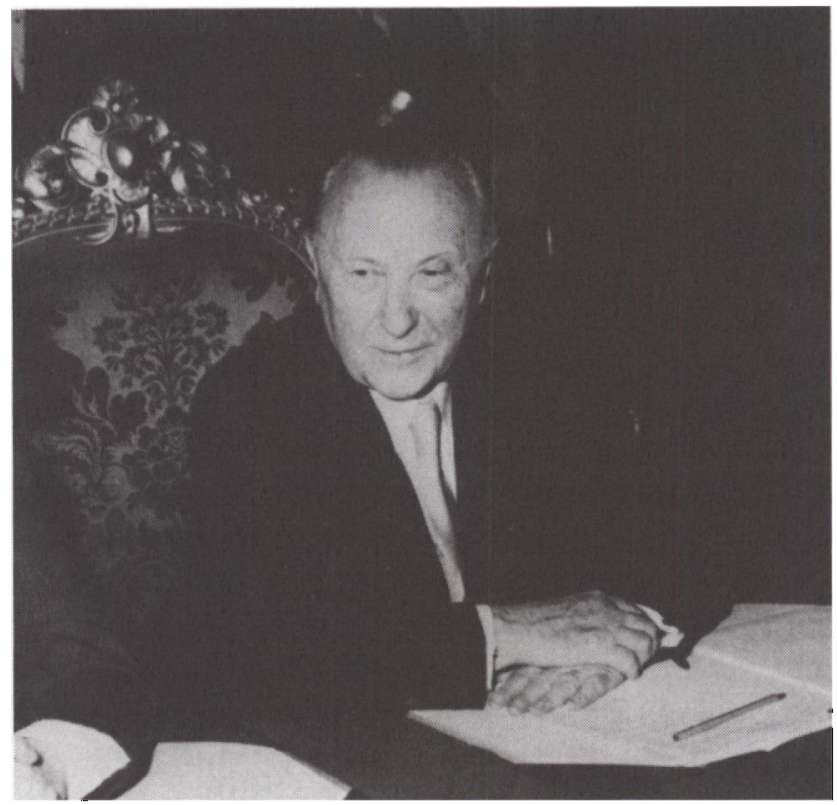

Dr. Konrad Adenauer, den vesttyske forbundskansler 1949-63. Adenauer pragede forberedelsen af normaliseringsprocessen $i$ granselandet, da han foranledigede en positiv tysk reaktion på det danske udspil om mindretalsproblemerne i efterdret 1954. Hans indfydelse på den konstruktive udvikling $i$ granselandet erkendes bedst, ndr man betanker, at det danske initiativ kunne vare modt med en fiasko, hvis forbundsregeringen havde afvist eller ignoreret de danske onsker om en afklaring pd problemerne $i$ Sydslesvig. (Det kgl. Bibliotek) 
I de andre NATO-landes delegationer var interessen for de sydslesvigske problemer oprindelig kun beskeden. Da H.C. Hansen fremlagde de danske synspunkter, betonede han, at behandlingen af mindretallet kunne få karakteren af et symbol på det fremtidige samarbejde, sådan som man gerne så det. I en pause under mødet blev der lejlighed til en kort drøftelse af sagen mellem H.C. Hansen og Dr. Adenauer, og denne erklærede bagefter over for pressen, at han ville medvirke til en positiv løsning. ${ }^{19}$

Troels Finks kommentar i gråbogen understreger, hvor delikat H.C. Hansens mission i Paris var: "Ved forbundskansler Dr. Adenauers udtalelse var risikoen for en tysk afvisning af sagen som NATO-samarbejdet uvedkommende bortelimineret«. Den ofte særdeles velinformerede tyske journalist Ernst Siegfried Hansen var en af de få, der havde haft blik for, at der havde været et risikomoment. Det kunne man læse i »Der Nordschleswiger « den 26. oktober 1954. "Der er grund til med Ernst Siegfried Hansen at understrege betydningen af, at en eventuel negativ slesvig-holstensk reaktion ikke fik lejlighed til at gøre sig gældende, fordi Dr. Adenauer umiddelbart reagerede positivt på udenrigsminister H.C. Hansens henvendelse. I første omgang var de udtalelser, der kom fra Slesvig-Holstens side, nemlig ikke særlig lovende ${ }^{20}$

\section{Udviklingen efter NATO-mødet i Paris}

Det første slesvig-holstenske udspil var da heller ikke særlig lovende. Den nye ministerpræsident Kai-Uwe von Hassel insisterede i en regeringserklæring den 8 . november 1954 , sådan som landsregeringen hidtil havde gjort, på en mindretalstraktat til løsning af grænselandsproblemerne. Erklæringen måtte i Danmark vække skuffelse. Den 12. november 1954 afviste den danske udenrigsminister tanken om en traktat. Flensburger Tageblatt luftede til gengæld den 13. november muligheden for en konstruktion, der gav ensartede grundsætninger for behandlingen af mindretallene uden at give anledning til fremmed indblanding. Fra dansk side var man klar over, at en afvisning af fælles forhandlinger ikke var mulig efter NATO-mødet i Paris; men man måtte regne med, at initiativet kom fra tysk side. Der kunne ikke være tale om et dansk initiativ. ${ }^{21}$

Ministerpræsident von Hassel i Kiel åbnede også en forhandlingskontakt til det danske mindretal. Landsregeringen var parat til indrøm- 
melser; men i Kiel satsede man officielt på en traktat, der måtte være "parallelitet nord og syd for grænsen «. ${ }^{22}$ Forespørgselsdebatten i forbundsdagen $8 .-10$. december 1954 virkede ligeledes forstemmende på danske kredse. Således kom CDU-politikeren Will Rasner, valgt i Flensborg, med flere let nedladende bemærkninger om Danmarks tidligere stormagtsstilling. I slutningen af 1954 var sagen ved at gå i hårdknude. Samtidig var der problemer med at få Folketinget til at ratificere Forbundsrepublikkens optagelse i NATO. Kort tid efter skulle Will Rasner imidlertid komme til at spille en meget konstruktiv rolle i det dansk-tyske forhold.

Den 13. januar 1955 meddelte Berlingske Tidende således i stor opsætning, at Folketingets udenrigsdebat om ratifikationen af det vesttyske NATO-medlemskab atter var blevet udsat. Begejstringen for at få Tyskland ind i NATO nu var ikke lige stor i alle parlamentariske kredse, således var de radikale betænkelige. Men så viste det sig, at et ganske opsigtsvækkende tysk udspil var under opsejling.

Gennem den konservative folketingsmand $\mathrm{K}$. Bøgholm havde kendte tyske politikere i Bonn, deriblandt den senere CDU-forbundskansler K.G. Kiesinger og Will Rasner haft følere fremme om nye dansk-tyske kontakter. Deres forståelse for dansk-tyske problemer var bl.a. kommet gennem kontakten til den tyskfødte Dr. Weltmann, der efter 1933 var blevet dansk statsborger og boede i København. I en samtale den 5. januar 1955 skitserede Will Rasner i et nyt oplæg forskellige løsninger for Bøgholm. Set fra officiel dansk side indeholdt Rasners ideer en rimelig forhandlingsbasis. Der ville ikke blive afkrævet det danske mindretal den kontroversielle loyalitetserklæring. En erklæring om grænsen var heller ikke aktuel. 5\%-klausulen ville blive ophævet, støtten til de danske skoler sat i vejret, og der kunne skabes basis for eksamensret til mindretalsskolerne. Det blev antydet, at hvis man ikke ønskede det, behøvede der ikke at blive tale om en mindretalstraktat eller noteudveksling, men om ensidige hensigtserklæringer, der nok bandt moralsk, men ikke folkeretsligt. K. Bøgholm skrev i sit referat til Udenrigsministeriet den 12. januar 1955 til sidst bl.a.: "Det er mit indtryk, at man fra tysk side ønsker en meget hurtig ordning af de spørgsmål, der her har været tale om, og at man nødig vil udsættes for, at ratifikationsdebatten $i$ det danske folketing giver anledning til angreb på den tyske politik i Sydslesvig. Heraf følger, at man efter min opfattelse vil nå det bedste resultat, dersom ordningen kan blive principielt gennemført inden ratifikationsdebatten. Enkelte spørgsmål, der 


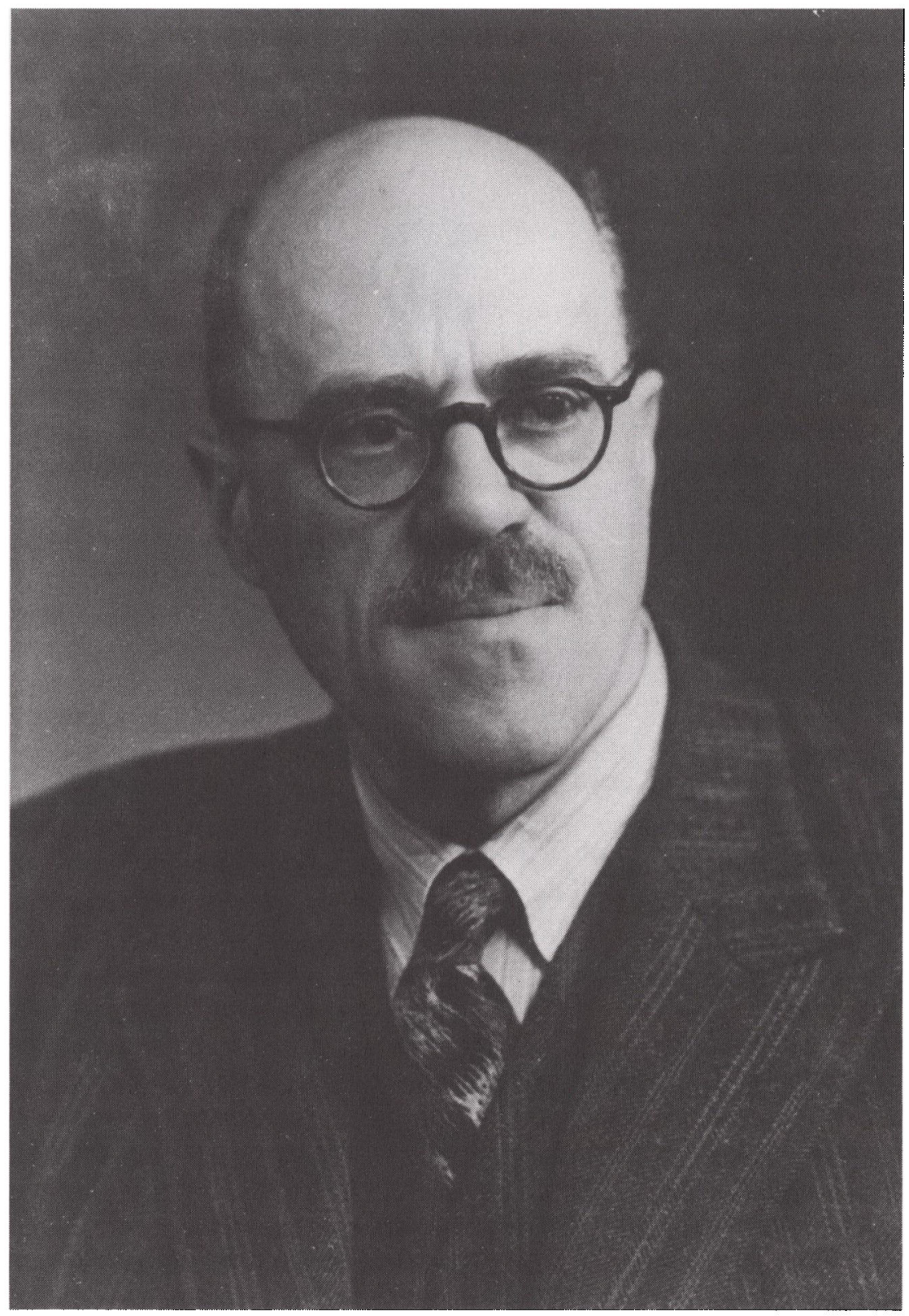

Den konservative folketingsmand og redaktor Karl Bøgholm. Han havde gennem sine europaiske kontakter, isar sine forbindelser til vesttyske politiske kredse, en vasentlig andel $i$ starten på den delikate proces, der forte til dansk-tyske forhandlinger og BonnKobenhavn erklaringerne. (Det kgl. Bibliotek) 
måtte vise sig at være af særlig kompliceret karakter, vil jo kunne tages ud til særlig behandling og behøver derfor ikke at sinke afgivelsen af den principielle erklæring.

Såvidt jeg kan skønne, vil den af Rasner nævnte tredie mulighed, (ensidige hensigtserklæringer, der ikke var folkeretslige bindende) der går tilbage til en samtale mellem Kiesinger og mig, være en god form, da regeringen derigennem kun fastlægger sin principielle politik overfor det danske folketing. ${ }^{23}$

Set fra en dansk synsvinkel var de nye tyske signaler særdeles betydningsfulde. "Når man betænker de udtalelser, der fra tysk side var fremsat om en loyalitetserklæring som forudsætning for indrømmelser med hensyn til 5\%-klausulen, og når man erindrer sig den hensigt, der på forskellig måde fik udtryk, at kun et afpolitiseret kulturelt mindretal kunne regne med tysk imødekommenhed, må man erkende, at der nu var tale om et iøjnefaldende omslag i tysk grænsepolitik, og at vejen blev banet for en løsning af de akutte spørgsmål«. ${ }^{24}$ Fra dansk side var man nu meget interesseret i en officiel formulering af den tyske henvendelse. Den kom, og i februar og marts 1955 forhandlede embedsmandsdelegationer sig frem til en formel for sameksistens i de danske og tyske mindretalsforhold. Som ønsket fra dansk side blev det fastholdt, at der ikke skulle være nogen mindretalstraktat, protokol, eller lignende, skønt den tyske delegation længe søgte at få en traktatlignende formel accepteret. Tyskerne gav langt de største indrømmelser; men de var også langt bagud med hensyn til liberale mindretalsordninger. Der blev givet tilsagn om, at spærreklausulen afskaffes. Dermed blev det vigtige spørgsmål om mindretallets politiske repræsentation i Kiel ordnet. Det danske mindretal kom heller ikke til at afgive nogen loyalitetserklæring. Derimod gik man fra dansk side med til en nyformulering af mindretalsrettighederne, mens man fra tysk side gav afkald på en gensidigt folkeretsligt forpligtende ordning og godkendte tanken om næsten enslydende, men formelt ensidige erklæringer, som hver regering for sig afgav. Vigtig var i denne forbindelse ikke mindst understregningen af, at mindretalsmedlemmers sindelag hverken må anfægtes eller efterprøves. Fra dansk side måtte man give adgang til oprettelsen af tyske eksamensskoler i Nordslesvig, skønt der var lokal modstand mod dette. ${ }^{25}$ De danske kirkeproblemer syd for grænsen kunne ikke løses i denne omgang, da den tyske landskirke var adskilt fra staten. Forholdene blev først ordnet tilfredsstillende i $1968 .{ }^{26}$

Hvem fandt frem til den elegante løsning med de formelt ensidige hensigtserklæringer, så man undgik de folkeretsligt bindende aftaler? 


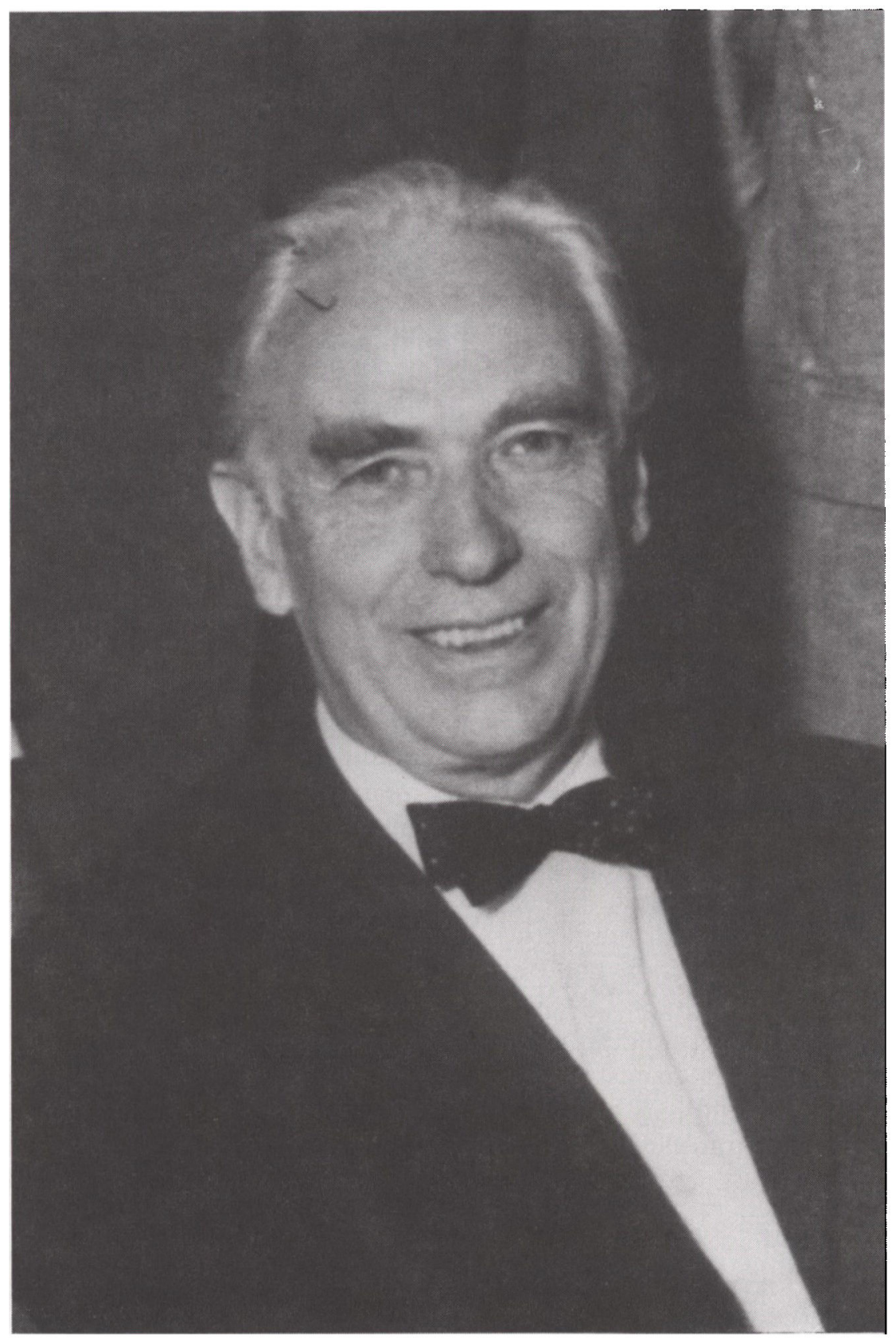

Professor, dr.phil Troels Fink, Udenrigsministeriets konsulent $i$ slesvigske spargsmål 1946-59. (Historiske Samlinger for Sonderjylland) 
Ambassadør Nils Svenningsen, der var leder af den danske forhandlingsdelegation, har generøst tilkendt Troels Fink æren. Selv om Troels Fink spillede sin betydelige rolle i forhandlingerne, er der dog her nok tale om en lille erindringsforskydning. Efter alt at dømme er løsningen et resultat af drøftelserne mellem K.G. Kiesinger, Will Rasner og K. Bøgholm. ${ }^{27}$ Bonn-Københavnerklæringerne af 29. marts 1955 betød fri bane for Vesttysklands optagelse i NATO. De var i deres formulering forst og fremmest en moralsk binding for mindretallenes to værtslande.

Troels Fink skrev i efteråret 1958, da gråbogen blev færdig, afsluttende følgende: "Det er endnu for tidligt at give den endelige historiske bedømmelse af de dansk-tyske mindretalsforhandlingers betydning. Det kan imidlertid konstateres, at den umiddelbare virkning har været gunstig. De mange ønsker om, at god vilje måtte blive lagt for dagen, synes stort set at være gået $\mathrm{i}$ opfyldelse. Mindretallenes stilling er blevet betrygget, og risikoen for international spænding i området ved den dansk-tyske grænse synes reduceret til et minimum. Afgørende i så henseende er dog næppe de konkrete forhandlingsresultater, men regeringernes ønske om, at problemerne i det slesvigske grænseområde ikke burde belaste det dansk-tyske forhold. Som udtryk for viljen til fredeligt samliv i pagt med demokratiets idealer har de dansktyske mindretalsforhandlinger $\mathrm{i}$ foråret 1955 deres særlige betydning . $^{28}$

I 30-året for erklæringerne kunne denne vurdering bekræftes fra begge sider. Den 16. maj 1985 mødtes den danske statsminister Poul Schlüter i Tønder med den tyske forbundskansler Helmut Kohl, og Poul Schlüter kunne her give det officielle Danmarks syn på erklæringernes betydning. Han udtalte bl.a.: "Vort møde her er et udtryk for det gode forhold mellem dansk og tysk, og jeg synes, at det varsler godt for vor fælles fremtid. Det er en meget velkommen anledning for Forbundsrepublikken og kongeriget til at markere 30-året for den danske regerings og forbundsregeringens erklæringer om det tyske, respektive det danske mindretals rettigheder. Disse erklæringer har deres væsentlige andel $i$, at vi kan se tilbage på tre årtiers positiv udvikling ikke blot i grænselandet, men også i forholdet mellem Danmark og Forbundsrepublikken.

De to erklæringer blev udfærdiget på et tidspunkt, hvor situationen i mange henseender var helt anderledes end den, vi kender $i$ dag. Det omfattende samarbejde på tværs af landegrænserne, som vi nu tager for givet, var endnu i sin vorden, og det krævede fantasi at forestille sig, 



\section{LITTERATUR OG KILDER}

Die Bonn-Kopenhagener Erklärungen von 1955. Zur Entstehung eines Modells für nationale Minderheiten. Herausgegeben vom Deutschen Grenzverein 1985.

Julius Feddersen: Die Grenzlandpolitik Friedrich Wilhelm Lübkes. 1979. (Forkortet: Feddersen).

Forhandlinger mellem Danmark og Tyskland i 1955 om de slesvigske mindretal. Udenrigsministeriet 1959. (Forkortet: gråbog),

Wilfried Lagler: Die Minderheitenpolitik der schleswigholsteinischen Landesregierung während des Kabinetts von Hassel (1954-1963). 1982. (Forkortet: Lager).

Helge Larsen og Roar Skovman (red): Festskrift til Troels Fink. 1982.

Anders Ture Lindstrøm: Landet Slesvig-Holstens politiske historie i hovedtræk 194554. 1975. (Forkortet: ATL).

Johan Peter Noack: Linier i britisk Sydslesvigpolitik 1945-48. S. 75-169 i Forskning i Sønderjylland. Årsberetning 1984 fra Institut for Grænseregionsforskning. 1985.

Heinz Josef Varain: Parteien und Verbände. Eine Studie über ihren Aufbau, ihre Verflechtung und ihr Wirken in Schleswig-Holstein 1945-1958. 1964. (Forkortet: Varain).

Grænsevagten

Folketingstidende

Fremtiden

\section{NOTER OG HENVISNINGER}

1. Johan Peter Noack: Linier i britisk Sydslesvigpolitik 1945-48, ATL s. 105-114. Fremtiden 181 s. 29.

2. Feddersen s. 354-68, ATL s. 134.

3. Gabriele Stüber: Der Kampf gegen den Hunger 1945-50. Studien zur Wirtschaftsund Sozialgeschichte Schleswig-Holsteins. Band 6. (1985)

4. Die Bonn-Kopenhagener-Erklärungen von 1955 s. 28.

5. Feddersen s. 486-97.

6. Die Bonn-Kopenhagener-Erklärungen von 1955 s. 25, Grænsevagten 1954 s. 310-11, ATL s. 129-30.

7. Feddersen s. 496-97, gråbog s. 10-14.

8. Gråbog s. 14.

9. Gråbog s. 13-17.

10. Gråbog s. 17.

11. Gråbog s. 19. Varain s. 240-45.

12. Varain s. $240-45$, Grænsevagten 1954 s. $310-11$, ATL s. $129-30$, 164-66.

13. Gråbog s. 22-23, 103-105.

14. Referat i Venstres gruppeprotokol 19. oktober 1954, Rigsarkivet.

15. Gråbog s. 22-25, Folketingstidende 1954-55 sp. 153-54, 307-08.

16. Gråbog s. 26-29, Lagler s. 68-69.

17. Gråbog s. 27.

18. Gråbog s. 27, Lagler s. 68-69.

19. Gråbog s. 28.

20. Gråbog s. 28-29. 
21. Gråbog s. 29-31.

22. Gråbog s. 32.

23. Gråbog s. 38-41, 99-103.

24. Gråbog s. 40-41.

25. Gråbog s. 48-58.

26. Gråbog s. 72, Lagler s. 132-36.

27. Gråbog s. 99-103, Nils Svenningsen: Dansk-tysk mindretalsordning, i Festskrift til Troels Fink s. 204-209. 1982. 